\title{
Development and fruit yield of strawberry plants as affected by crown diameter and plantlet growing period
}

\author{
Carine Cocco $^{(1)}$, Jerônimo Luiz Andriolo ${ }^{(1)}$, Lígia Erpen ${ }^{(1)}$, Francieli Lima Cardoso ${ }^{(1)}$ and Gustavo Spreckelsen Casagrande ${ }^{(1)}$ \\ (1)Universidade Federal de Santa Maria, Centro de Ciências Rurais, Avenida Roraima, 1000, Bairro Camobi, CEP 97105-900 Santa \\ Maria, RS, Brasil. E-mail: carinecocco@yahoo.com.br, jeronimo@pq.cnpq.br, ligia_erpen@yahoo.com.br, francyacecy@hotmail.com, \\ gustavospreckelsen@hotmail.com
}

\begin{abstract}
The objective of this work was to evaluate the influence of crown diameter and growing period of runner tips in 128 cell-trays on growth and yield of strawberry in the field. Treatments consisted of three classes of runner tip crown diameters, between 2.0 to $3.9 \mathrm{~mm}$; 4.0 to $5.5 \mathrm{~mm}$ and 5.6 to $7.0 \mathrm{~mm}$, respectively, and four growing periods in trays, 24; 39; 54 and 69 days, respectively. Higher shoot dry mass of transplants at planting and earlier yield of plants in the field were obtained in transplants grown for 69 days in trays. Larger runner tips lead to more vigorous transplants at planting and plants with higher vegetative growth in the field, with minor impact on yield. Increasing the growing time of runner tips in trays improved early fruit yield and decreased plant vegetative growth in the field.
\end{abstract}

Index terms: Fragaria x ananassa, early yield, propagation, plug plants.

\section{Desenvolvimento e produtividade do morangueiro influenciados pelo diâmetro da coroa e período de crescimento de mudas}

\begin{abstract}
Resumo - O objetivo deste trabalho foi avaliar a influência do diâmetro das pontas de estolão e do seu período de crescimento em bandejas sobre o crescimento da planta e produtividade do morangueiro Arazá. Os tratamentos consistiram em três classes de diâmetro das pontas de estolão: entre 2,0 e 3,9 mm; 4,0 e 5,5 mm e 5,6 e 7,0 mm, e quatro períodos de crescimento nas bandejas: 24; 39; 54 e 69 dias. Maior massa seca vegetativa das mudas no plantio e maior produção precoce das plantas foram obtidas com mudas que cresceram 69 dias nas bandejas. Pontas de estolão de maior diâmetro originaram mudas mais vigorosas no plantio e plantas com maior crescimento vegetativo no campo, sem efeito na produtividade de frutas. $\mathrm{O}$ aumento do período de crescimento das mudas nas bandejas aumentou a produção precoce de frutas e diminuiu o crescimento vegetativo das plantas no campo.
\end{abstract}

Termos para indexação: Fragaria x ananassa, precocidade, propagação, muda com torrão.

\section{Introduction}

In the propagation of strawberry plants, explants are harvested from a clonal garden and multiplied in vitro for several generations. After acclimatization, they are planted as stock plants for vegetative growth, emission of stolons and production of transplants. That later step is critical, since yield of the crop depends on the quality of the transplants.

Bare root is the traditional production method of strawberry transplants. It causes mechanical damage to the root system at planting and high risk of contamination by pathogens. As a consequence, several plants die in the first week after planting and vegetative growth is slow, delaying the onset of fruiting and reducing fruit yield and quality (Durner et al., 2002).

An alternative method for the production of strawberry transplants is that known as plug plants. In this method, runner tips are collected from stock plants at the emission of the first root primordia and rooted in trays with substrate. They are later shipped for sale with roots coated in the substrate, thus eliminating most of the disadvantages of bare root transplants. Plug transplants reach the conditions reported by Latimer (1998) for quality of transplant production in nurseries: 1) they withstand the stress of handling, transportation and transplanting, 2) they adapt quickly to the field environment, 3) they establish and resume active growth soon after transplanting, and 4) they produce

Pesq. agropec. bras., Brasília, v.45, n.7, p.730-736, jul. 2010 
acceptable yield without reduction or delay compared to other establishment methods. As to plug plants, survival after planting is enhanced and initial growth is faster, resulting in earlier (Fernandez \& Ballington, 2003; Takeda \& Hokanson, 2003) and higher fruit yield and quality (Hochmuth et al., 2006a, 2006b; Durner et al., 2002; Takeda \& Hokanson, 2003; Giménez et al., 2009).

Strawberry yield is affected by the physiological quality of transplants. Young and vigorous transplants produce plants with higher vegetative growth and fruit yield than weak and old ones, and they also reduce management practices (Hicklenton \& Reekie, 2002). A positive correlation between transplant crown diameter and total fruit yield has been reported in the literature (Faby, 1997). Large-crowned plants produced higher early season yield than small-crowned plants (Albregts, 1968; Durner et al., 2002). The main variable that has been used to identify the quality of strawberry transplants is the crown diameter, which must be over $8 \mathrm{~mm}$ (Durner et al., 2002).

The time that plug transplants remain in trays may affect their growth and development. The period must be long enough for the emission of new roots and leaves and storage of assimilates before planting in the field. On the other hand, if this period is too long, competition for radiation may occur, and root growth may be restricted by the size of the container, with reduced growth and delay in the development, affecting the survival of transplants at planting and fruit yield of plants in the field, irrespective of the crown diameter of the transplants (Bish et al., 2002; Hochmuth et al., 2006a, 2006b).

The objective of this work was to evaluate the effect of crown diameter and period of transplants in trays on growth, development and fruit yield of 'Arazá' strawberry plants in the field.

\section{Materials and Methods}

The experiment was carried out in 2009 at Departamento de Fitotecnia, Universidade Federal de Santa Maria, Santa Maria, Rio Grande do Sul, Brazil $\left(29^{\circ} 42^{\prime} \mathrm{S}, 53^{\circ} 42^{\prime} \mathrm{W}\right.$, altitude: $\left.95 \mathrm{~m}\right)$. The climate is subtropical humid by Köppen's classification, with monthly average temperatures ranging between 3 and $22^{\circ} \mathrm{C}$ and annual rainfall of about $1,769 \mathrm{~mm}$ (Moreno, 1961).
The strawberry cultivar used was Arazá (INIA, Uruguay). It is a short-day, intermediate vigor and early yield cultivar, derived from a cross between Uruguayan A07.04 (Oso Grande x Sweet Charlie) and C01.05 (Addie x Sweet Charlie) (Giménez et al., 2003). For the production of runner tips, explants were collected at the beginning of January of 2008, in the strawberry clonal garden. After four in vitro multiplications, they were acclimatized in a polyethylene greenhouse with $80 \%$ transmissivity, for 30 days between August, $31^{\text {th }}$ and September, $30^{\text {th }}, 2008$, in a closed soilless system, using sand as substrate (Bisognin, 2007).

After acclimatization, they were transplanted as stock plants in $2.3 \mathrm{dm}^{3}$ polyethylene bags, filled with the organic substrate Plantmax HA and placed on top of a polyethylene film-covered-bed, $80 \mathrm{~cm}$ above the soil surface. The substrate bulk density was $0.405 \mathrm{~kg} \mathrm{dm}^{-3}$ and the water retention capacity $0.466 \mathrm{~L} \mathrm{dm}^{-3}$. A distance of $0.27 \mathrm{~m}$ among rows and $0.30 \mathrm{~m}$ among bags was used, in a plant density of 12 plants $\mathrm{m}^{-2}$. Water and nutrients were supplied daily by fertigation, using the nutrient solution adjusted by Andriolo (2007), in mmol L-1: $10.6 \mathrm{NO}_{3}^{-} ; 0.43 \mathrm{NH}_{4}^{+}$; $2 \mathrm{H}_{2} \mathrm{PO}_{4} ; 6.15 \mathrm{~K}^{+} ; 3.0 \mathrm{Ca}^{2+} ; 1 \mathrm{Mg}^{2+}$ and $1 \mathrm{SO}_{4}^{2-}$; and in $\mathrm{mg} \mathrm{L}^{-1}: 0.03 \mathrm{Mo} ; 0.42 \mathrm{~B} ; 0.06 \mathrm{Cu} ; 0.50 \mathrm{Mn} ; 0.22 \mathrm{Zn}$ and $1.0 \mathrm{Fe}$. The $\mathrm{pH}$ and electrical conductivity were maintained between 5.5 and 6.5 and between 1.4 and $1.5 \mathrm{dS} \mathrm{m}^{-1}$, respectively.

To obtain plants on different growing periods in trays, runner tips were collected from the stock plants on four dates: February 11 and $26^{\text {th }}$, March 13 and $28^{\text {th }}, 2009$, totalizing 24, 39, 54 and 69 days, respectively. They were separated by crown diameter into three classes: 2.0 to $3.9 \mathrm{~mm}$ (class 1); 4.0 to $5.5 \mathrm{~mm}$ (class 2) and 5.6 to $7.0 \mathrm{~mm}$ (class 3) (Durner et al., 2002). Runner tips of each class were rooted in separate 128 cell polystyrene trays filled with $62 \mathrm{~cm}^{3}$ of the commercial substrate Plantmax HA and placed for one week in a moist chamber under sprinkler irrigation for $5 \mathrm{~min}$ eight times a day. Afterwards, trays were transferred to benches inside the polyethylene greenhouse, under the same conditions of sprinkler irrigation, and fertigated twice a week using the same nutrient solution as the stock plants.

Treatments were the three crown diameter classes of runner tips collected from the stock plants and four periods of transplants in trays, 24, 39, 54 and 69 days, in a $4 \times 3$ factorial randomized block design, with four replications and 16 plants per plot $\left(2.60 \mathrm{~m}^{-2}\right)$. 
Transplants of all treatments were planted in the field on April 20 $0^{\text {th }}$, and the experiment was terminated on December $1^{\text {st }}, 2009$. Before planting, older leaves were removed. Roots longer than $10 \mathrm{~cm}$ were excised (Antunes \& Duarte Filho, 2003). The remaining leaves were recorded, the crown diameter measured and shoot and root dry mass determined after drying at $65^{\circ} \mathrm{C}$ until constant mass was achieved. A sample of four plants in each treatment was used for determination.

Planting in the field was performed on $1.10 \mathrm{~m}$ width polyethylene mulched raised beds, with a plant density of 6.6 plants $\mathrm{m}^{-2}(0.40 \mathrm{x} 0.40 \mathrm{~m})$, under $0.70 \mathrm{~m}$ high $100 \mu \mathrm{m}$ polyethylene tunnels. In sunny days, tunnels were opened at sunrise and closed at sunset and kept closed on cloudy or rainy days. Water and nutrients were supplied by dripping according to recommendations of Santos \& Medeiros (2003).

Number of days from planting to the beginning of flowering and to the first fruit harvest were recorded when $50 \%$ of the plants in the plot had at least one flower and one ripe fruit, respectively. Ripe fruits were harvested twice a week at $100 \%$ red epidermis, identified by the phenological stage 87 (Meier et al., 1994). They were counted, weighted and screened as marketable, when the fresh mass surpassed $10 \mathrm{~g}$, and unmarketable when it was below $10 \mathrm{~g}$. Early fruit production was considered from the beginning of the harvest to September 30 $0^{\text {th }}, 2009$ and total fruit production, from the beginning of the harvest to December $1^{\text {st }}, 2009$. At the end of the experiment, four plants from each treatment were removed from the soil. The crown diameter, number of crowns and number of leaves were counted and dry mass of shoot and roots was determined after drying at $65^{\circ} \mathrm{C}$ until constant mass was recorded.
The fulfillment of assumptions of the mathematical model for analysis of variance was verified by the error normality test. The variable number of fruits, leaves and crowns were transformed using the expression ( $\mathrm{x}$ $+0.05)^{0.5}$. All variables were submitted to analysis of variance and the significance of differences among means was determined by the Tukey's test at 5\% probability or polynomial regression.

\section{Results and Discussion}

No significant interactions were found between crown diameters of runner tips and growing period of transplants in trays. The number of leaves of transplants at planting was similar among runner tip crown diameter classes, with an average of 4.5 leaves per transplant (Table 1). At planting, crown diameter, shoot and root dry mass were higher on transplants from class 3 runner tips. At the end of the experiment, number of leaves, shoot and root dry mass of plants were also higher in those originated from class 3 runner tips. Number of crowns did not differ among plants originated from the three runner tip classes and the crown diameter was lower on plants from class 1 runner tips. Earlier flowering and fruit harvest were recorded on plants from class 3 runner tips ( $p>0.05$ ).

The time the transplants spent in the trays affected growth and development (Figure 1). At planting, a positive quadratic polynomial model was fitted for the number of leaves (Figure $1 \mathrm{~A}$ ), showing a strong increase affected by the growing period in trays. The crown diameter did not differ significantly $(p>0.05$, $F$ test) while shoot dry mass increased linearly (Figure $1 \mathrm{C}$ ). The number of days from planting to the beginning of flowering and fruit harvest decreased

Table 1. Number of leaves (NL), crown diameter (CD), shoot dry mass (SDM) and root dry mass (RDM) of strawberry transplants at planting and number of leaves (NL), crown diameter (CD), number of crowns (NC), shoot dry mass (SDM) and root dry mass $(\mathrm{RDM})$ of plants at the end of the experiment ${ }^{(1)}$.

\begin{tabular}{|c|c|c|c|c|c|c|c|c|c|c|}
\hline \multirow{2}{*}{$\begin{array}{l}\text { Crown } \\
\text { class }\end{array}$} & \multirow{2}{*}{$\begin{array}{c}\text { Diameter } \\
(\mathrm{mm})\end{array}$} & \multicolumn{4}{|c|}{ Planting } & \multicolumn{5}{|c|}{ End of experiment } \\
\hline & & NL & $\begin{array}{c}\mathrm{CD} \\
(\mathrm{mm})\end{array}$ & $\begin{array}{c}\text { SDM } \\
\left(\text { g plant }^{-1}\right)\end{array}$ & $\begin{array}{c}\text { RDM } \\
\left(\text { g plant }^{-1}\right)\end{array}$ & NL & $\begin{array}{c}\mathrm{CD} \\
(\mathrm{mm})\end{array}$ & $\mathrm{CN}$ & $\begin{array}{c}\text { SDM } \\
\left(\text { g plant }^{-1}\right)\end{array}$ & $\begin{array}{c}\mathrm{RDM} \\
\left(\mathrm{g} \mathrm{plant}^{-1}\right)\end{array}$ \\
\hline 1 & $2.0-3.9$ & $4.37 \mathrm{a}$ & $5.18 b$ & $0.42 \mathrm{~b}$ & $0.15 b$ & $31.4 \mathrm{~b}$ & $13.1 \mathrm{~b}$ & $4.2 \mathrm{a}$ & $14.02 \mathrm{~b}$ & $2.67 b$ \\
\hline 2 & $4.0-5.5$ & $4.43 \mathrm{a}$ & $5.68 \mathrm{~b}$ & $0.52 b$ & $0.16 b$ & $30.6 b$ & $15.3 \mathrm{a}$ & $3.9 \mathrm{a}$ & $15.14 b$ & $2.99 \mathrm{~b}$ \\
\hline 3 & $5.5-6.9$ & $4.87 \mathrm{a}$ & $7.47 \mathrm{a}$ & $0.72 \mathrm{a}$ & $0.29 \mathrm{a}$ & $40.8 \mathrm{a}$ & $15.5 \mathrm{a}$ & $4.8 \mathrm{a}$ & $19.62 \mathrm{a}$ & $4.30 \mathrm{a}$ \\
\hline$\overline{\mathrm{CV}(\%)}$ & & 21.3 & 14.5 & 27.2 & 40.3 & 8.7 & 8.8 & 10.8 & 20.9 & 26.6 \\
\hline DMS & & 0.84 & 0.77 & 0.13 & 0.07 & 5.42 & 1.11 & 0.88 & 2.92 & 0.81 \\
\hline
\end{tabular}

${ }^{(1)}$ Means followed by same letter in column do not differ by Tukey test, at $5 \%$ probability. 
linearly (Figure $1 \mathrm{D})$. At the end of the experiment, the effect of the time of transplants in trays on number of leaves on the plant was weak (Figure $1 \mathrm{~A}$ ). Crown diameter (Figure 1 B) and shoot dry mass (Figure 1 C) follow a polynomial quadratic model.

At the end of the early yield period, number of leaves and fruit yield were lower on plants originated from class 1 runner tips (Table 2). Fruit weight did not differ among treatments, with an average of $11.4 \mathrm{~g}$ fruit $^{-1}$. At the end of the experiment, number of leaves, total fruit yield and fruit mass did not differ among plants originated from all runner tip classes and means were 48.8 fruit plant ${ }^{-1}, 461.9$ g plant $^{-1}$ and 9.5 g fruit $^{-1}$, respectively.
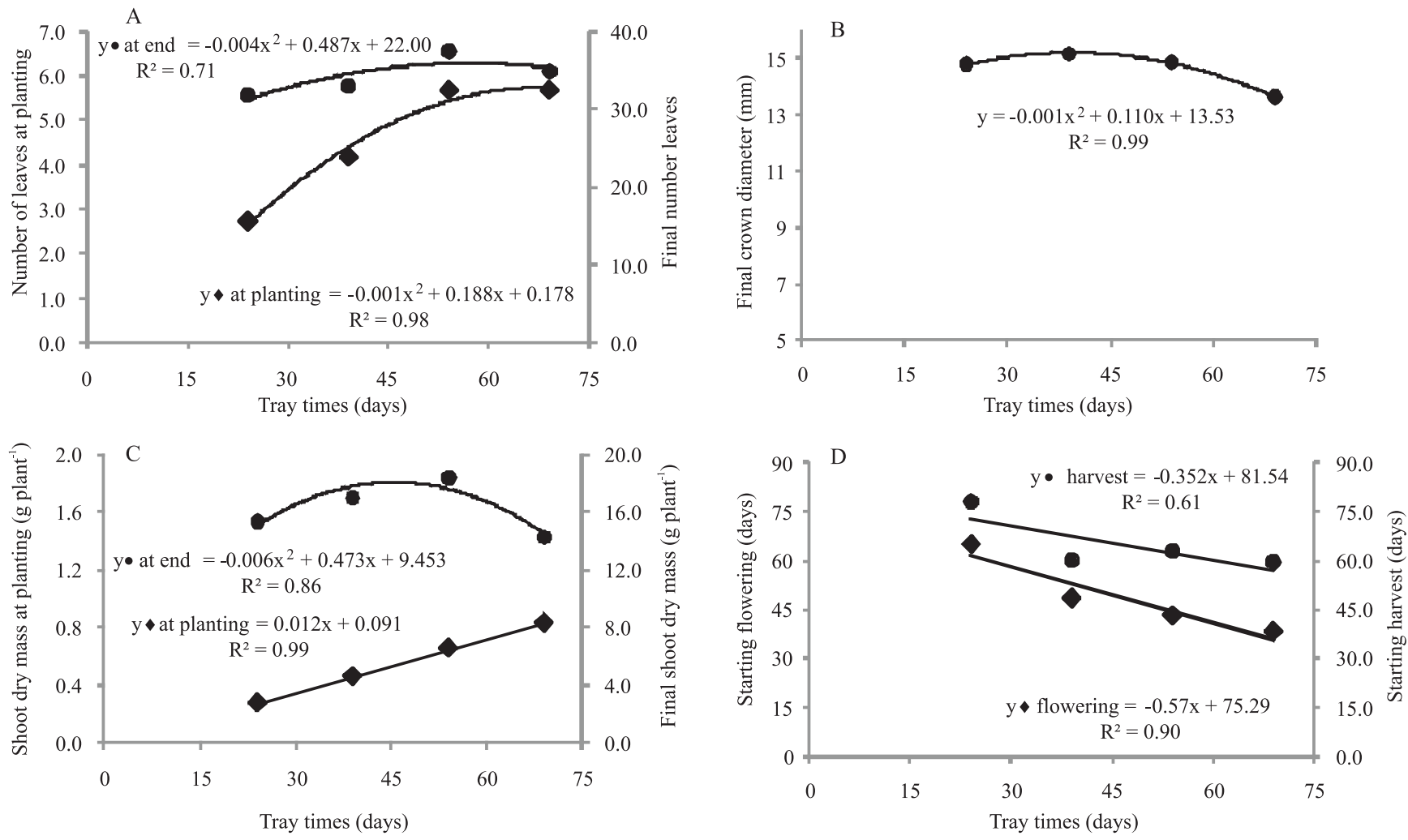

Figure 1. Number of leaves of transplants at planting and of plants at the end of the experiment (A), crown diameter of plants at the end of the experiment (B), shoot dry mass of transplants at planting and of plants at the end of the experiment (C) and number of days until onset of flowering and fruit harvest (D) on plants from 24, 39, 54 and 69 days as growing periods of transplants.

Table 2. Beginning of flowering and fruiting, number of fruits (NF), fruit yield (FY) and fruit mass (FW) in early and total yield at the end of the experiment with strawberry plants originated from three crown diameter classes of runner tips ${ }^{(1)}$.

\begin{tabular}{|c|c|c|c|c|c|c|c|c|c|}
\hline \multirow{2}{*}{$\begin{array}{l}\text { Crown } \\
\text { class }\end{array}$} & \multirow{2}{*}{$\begin{array}{c}\text { Diameter } \\
(\mathrm{mm})\end{array}$} & \multirow{2}{*}{$\begin{array}{c}\text { Flowering } \\
\text { (days) }\end{array}$} & \multirow{2}{*}{$\begin{array}{c}\text { Fruiting } \\
\text { (days) }\end{array}$} & \multicolumn{3}{|c|}{ Early yield } & \multicolumn{3}{|c|}{ Total yield } \\
\hline & & & & NF & $\begin{array}{c}\mathrm{FY} \\
\left(\mathrm{g}_{\text {plant }}{ }^{-1}\right)\end{array}$ & $\begin{array}{c}\text { FW } \\
\left(\text { g fruit }^{-1}\right)\end{array}$ & NF & $\begin{array}{c}\text { FY } \\
\left(\text { g plant }^{-1}\right)\end{array}$ & $\begin{array}{c}\text { FW } \\
\text { (g fruit }^{-1} \text { ) }\end{array}$ \\
\hline 1 & $2.0-3.9$ & $57.4 \mathrm{a}$ & $69.5 \mathrm{a}$ & $14.3 b$ & $164.2 b$ & $11.6 \mathrm{a}$ & $46.5 a$ & $440.0 \mathrm{a}$ & $9.4 \mathrm{a}$ \\
\hline 2 & $4.0-5.5$ & $43.4 b$ & $63.2 b$ & $17.1 \mathrm{a}$ & $192.9 \mathrm{ab}$ & $11.3 \mathrm{a}$ & $48.9 \mathrm{a}$ & $470.1 \mathrm{a}$ & $9.6 \mathrm{a}$ \\
\hline 3 & $5.5-6.9$ & $45.6 \mathrm{~b}$ & $62.8 b$ & $18.8 \mathrm{a}$ & $208.5 \mathrm{a}$ & $11.2 \mathrm{a}$ & $51.0 \mathrm{a}$ & $475.8 \mathrm{a}$ & $9.4 \mathrm{a}$ \\
\hline $\mathrm{CV}(\%)$ & & 15.1 & 6.7 & 19.6 & 19.0 & 11.1 & 18.1 & 20.1 & 8.0 \\
\hline DMS & & 6.4 & 3.9 & 2.8 & 31.1 & 1.1 & 7.7 & 80.7 & 0.6 \\
\hline
\end{tabular}

${ }^{(1)}$ Means followed by same letter in column do not differ by Tukey test, at $5 \%$ probability. Early yield, from the beginning of the harvest to September $30^{\text {th}}$; total yield, from the beginning of the harvest to December, $1^{\text {st }}$. 
Number and early fruit yield were affected by the period of transplants in trays (Figure 2). Older transplants produced more fruit and higher yield of plants in the field, at a rate of 0.13 fruits day ${ }^{-1}$ and $1.17 \mathrm{~g} \mathrm{day}^{-1}$, respectively. A similar linear relationship was found between early fruit yield of plants in the field and shoot dry mass of transplants at planting (Figure 3 ).

Results show that larger runner tips (class 3 ) produce more vigorous transplants at planting and plants with higher vegetative growth in the field (Table 1). This is in agreement with recommendations of Durner et al. (2002) for using strawberry transplants with a crown diameter over $8 \mathrm{~mm}$. Nevertheless, it is surprising that the effect of plant vigor on fruit yield was of minor importance. In fact, only the smallest runner tips (class 1) reduced early number and fruit yield of plants in the field, without any significant effect on total yield (Table 1). A hypothesis that may explain this apparent discrepancy is the indirect influence of growth on plant development. Although plant developmental stages have been associated with thermal units (Andriolo et al., 2003; Streck et al., 2005), plants have to attain a minimum size in their current development stage before going to the next one, regardless of favorable environmental conditions.

In this sense, more vigorous transplants at planting could produce and store assimilates in a shorter time, reaching the physiological conditions for flowering before less vigorous transplants. This is supported by the early flowering and fruit harvest recorded on plants from class 3 transplants. Nevertheless, this effect would be buffered onwards, as vegetative growth, flowering and fruit growth in the strawberry plant are

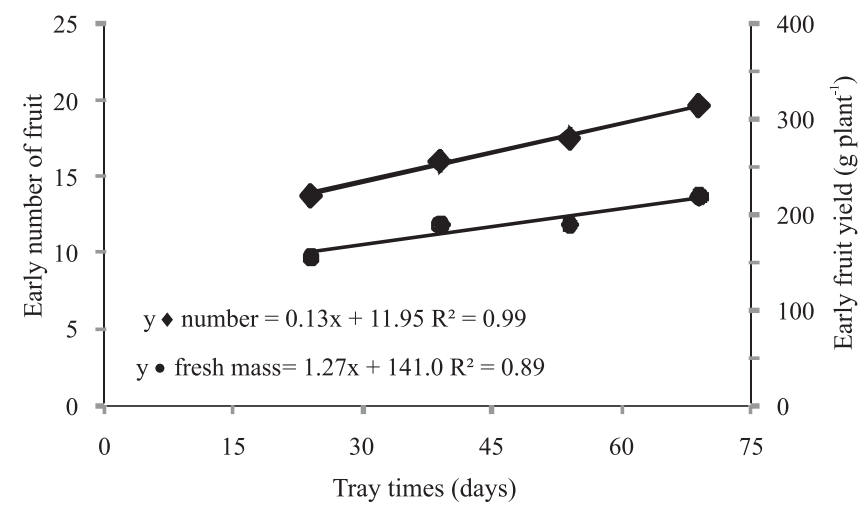

Figure 2. Relationship between early number and early fruit yield of strawberry plants and the time growing period of transplants in trays. simultaneous and indeterminate processes that continue while environmental conditions are favorable. As a consequence, the effect of transplant vigor at planting on further early yield of plants in the field becomes diluted on the scale of total yield.

The above hypothesis could also explain the effect of the time growing period in trays on number of leaves of transplants at planting and of plants in the field (Figure $1 \mathrm{~A}$ ). More time in the trays led to higher number of leaves at planting. Nevertheless, the relationship was polynomial, as transplants at times 54 and 69 did not differ significantly by the $t$ test ( $p>0.05$ ). However, during these times in trays, shoot growth of transplants did not show any tendency of reduction (Figure $1 \mathrm{C}$ ). This implies that growth was not affected by restrictions in root growth induced by the small volume of the tray cells, as reported in the literature (Hamann \& Poling, 1997).

It is possible that the lower number of leaves at time period 69 was an artifact derived from the competition for light. Theoretical models used to explain the absorption of radiation by plant canopies state that the stabilization of the leaf area index (LAI) is a consequence of senescence and death of basal leaves caused by a shut-down of the photosynthetic rate below the compensation level (Gautier et al., 2001). Thus, the number of leaves on transplants at time period $69 \mathrm{did}$ not increase, while the growth of young leaves did, without reduction in shoot growth.

The time of transplants in trays only improved early fruit yield and, at the end of the experiment, lower vegetative growth was recorded on plants originated from older transplants (Figure $1 \mathrm{~B}, \mathrm{C}$ ). This was

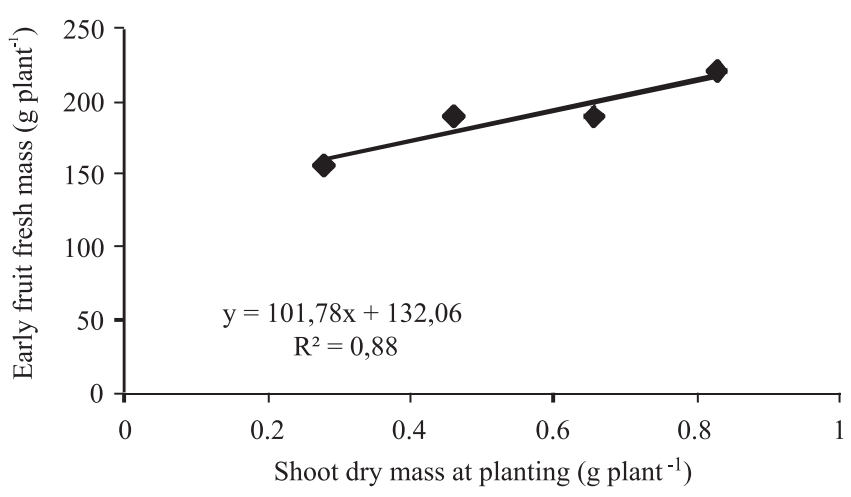

Figure 3. Relationship between early fruit yield of plants and shoot dry mass of strawberry plants and the time growing period of transplants in trays. 
surprising, as higher vegetative growth and total fruit yield was expected in plants originated from these more vigorous transplants. The hormonal balance of stock plants and runner tips may be the reason. More vigorous older transplants were obtained from runner tips collected in February, under middle summer conditions, when flowering is inhibited by high temperatures and emission of stolons is stimulated by hormonal plant effects. Runner tips grown in summer possibly have some inhibitors that delay flowering and harvesting on plants in the field. Although this is supported by data in Figure $1 \mathrm{D}$, further research is necessary.

Results of this research show technological implications. Firstly, the crown diameter itself is not an efficient quality descriptor of strawberry transplants. It should be used together with other variables such as number of leaves or size of the transplant. Secondly, the environmental conditions at the time runner tips are collected should be considered. This imposes additional practical difficulties for nurseries in the commercial production of strawberry plug transplants. They search for extending the production time period of transplant production by collecting runner tips early in summer and rooting them in big tray cells or containers. In face of the present results, when this is accomplished, the inhibitory effect of high temperatures on flowering should be considered. Conditioning by artificial chilling, as in Unites States (Bish et al., 1997, 2002; Durner et al., 2002) and Europe (Faby, 1997; Lieten, 2000) for glasshouse forcing in winter, may be an alternative, but further research is needed to evaluate local conditions.

\section{Conclusions}

1. Larger runner tips lead to more vigorous strawberry transplants at planting, early yield and plants with higher vegetative growth in the field, with minor influence on fruit yield.

2 . Increasing the growing time of runner tips in trays improves early fruit yield and decreases strawberry plant vegetative growth.

\section{Acknowledgments}

To Conselho Nacional de Desenvolvimento Científico e Tecnológico, for financial support; to Coordenação de Aperfeiçoamento de Pessoal de Nível Superior, for a scholarship.

\section{References}

ALBREGTS, E.E. Influence of plant size at transplanting on strawberry fruit yield. Proceedings of the Florida State Horticultural Society, v.81, p.163-166, 1968.

ANDRIOLO, J.L. Preparo e manejo da solução nutritiva na produção de mudas e de frutas do morangueiro. In: SEMINÁRIO SOBRE O CULTIVO HIDROPÔNICO DE MORANGUEIRO, 1., 2007, Santa Maria. Anais. Santa Maria: UFSM, 2007. p.41-50.

ANDRIOLO, J.L.; ESPÍNDOLA, M.C.G.; ESTEFANELLO, M.O. Crescimento e desenvolvimento de plantas de alface provenientes de mudas com diferentes idades fisiológicas. Ciência Rural, v.33, p.1-15, 2003.

ANTUNES, L.E.C.; DUARTE FILHO, J. Produção de mudaS. In: ANTUNES, L.E.C. (Ed.). Sistema de produção do morango. Pelotas: Embrapa Clima Temperado, 2003. (Embrapa Clima Temperado. Sistemas de produção, 5).

BISH, E.B.; CANTLIFFE, D.J.; CHANDLER, C.K. Temperature conditioning and container size affect early season fruit yield of strawberry plug plants in a winter, annual hill production system. HortScience, v.37, p.762-764, 2002.

BISH, E.B.; CANTLIFFE, D.J.; HOCHMUTH, G.J.; CHANDLER, C.K. Development of containerized strawberry transplants for Florida's winter production system. Acta Horticulturae, n.439, p.461-468, 1997.

BISOGNIN, D.A. Produção de plantas matrizes de morangueiro. In: SEMINÁRIO SOBRE O CULTIVO HIDRÔPONICO DE MORANGUEIRO, 1., 2007, Santa Maria. Anais. Santa Maria: UFSM, 2007. p.9-17.

DURNER, E.F.; POLING, E.B.; MAAS, J.L. Recent advances in strawberry plug transplant technology. HortTechnology, v.12, p.545-550, 2002.

FABY, R. The productivity of graded "Elsanta" frigo plants from different origin. Acta Horticulturae, n.439, p.449-455, 1997.

FERNANDEZ, G.E.; BALLINGTON, J.R. Double cropping of strawberries in an annual system using conditioned plug plants and high tunnels. Acta Horticulturae, n.614, p.547-552, 2003.

GAUTIER, H.; GUICHARD, S.; TCHAMITCHIAN, M. Modulation of competition between fruits and leaves by flower pruning and water fogging, and consequences on tomato leaf and fruit growth. Annals of Botany, v.88, p.645-652, 2001.

GIMÉNEZ, G.; ANDRIOLO, J.L.; JANISH, D.J.; COCCO, C.; DAL PICIO, M. Cell size in trays for the production of strawberry plug transplantS. Pesquisa Agropecuária Brasileira, v.44, p.726-729, 2009.

GIMÉNEZ, G.; VICENTE, E.; MANZZIONI, A. El cultivar de frutilla INIA Arazá. Montevideo: Instituto Nacional de Investigación Agropecuaria, 2003. 4p. (INIA. Hoja de divulgación, 83).

HAMANN, K.K.; POLING, E.B. The influence of runner order, night temperature and chilling cycles on the earliness of "Selva" plug plants fruit production. Acta Horticulturae, n.439, p.597-604, 1997. 
HICKLENTON, P.R.; REEKIE, J.Y.C. The nursery connection: exploring the links between transplant growth and development, establishment, and productivity. In: HOKANSON, S.; JAMIESON, A. (Ed.). Strawberry research to 2001. Alexandria: ASHS, 2002. p.136-146.

HOCHMUTH, G. CANTLIFFE, D.; CHANDLER, C.; STANLEY, C.; BISH, E.; WALDO, E.; LEGARD, D.; DUVAL, J. Containerized strawberry transplants reduce establishment-period water use and enhance early growth and flowering compared with bare-root plants. HortTechnology, v.16, p.46-54, 2006a.

HOCHMUTH, G.; CANTLIFFE, D.; CHANDLER, C.; STANLEY, C.; BISH, E.; WALDO, E.; LEGARD, D.; DUVAL, $\mathrm{J}$. Fruiting responses and economics of containerized and bare root strawberry transplants established with different irrigation methods. HortTechnology, v.16, p.205-210, 2006 b.

LATIMER, J.G. Mechanical conditioning to control height. HortTechnology, v.8, p.529-534, 1998.

LIETEN, F. Recent advances in strawberry plug transplant technology. Acta Horticulturae, n.513, p.383-388, 2000.
MEIER, U.; GRAF, H.; HACK, M.; HESS, M; KENNEL, W.; KLOSE, R.; MAPPES, D.; SEIPP, D.; STAUSS, R.; STREIF, J.; VAN DEN BOOM, T. Phänologische Entwick-lungsstadien des Kernobstes (Malus domestica Borkh. und Pyrus communis L.), des Steinobstes (Prunus-Arten), der Johannisbeere (Ribes-Arten) und der Erdbeere (Fragaria $\mathrm{x}$ ananassa Duch.). Nachrichtenblatt Deutscher Pflanzenschutzdienst, v.46, p.141-153, 1994.

MORENO, J.A. Clima do Rio Grande do Sul. Porto Alegre: Secretaria da Agricultura, 1961. 41p.

SANTOS, A.M. dos; MEDEIROS, A.R.M. de (Ed.). Morango: produção. Pelotas: Embrapa Clima Temperado; Brasília: Embrapa Informação Tecnológica, 2003. 81p. (Frutas do Brasil, 40).

STRECK, N.A.; TIBOLA, T.; LAGO, I.; BURIOL, G.A.; HELDWEIN, A.B.; SCHNEIDER, F.M.; ZAGO, V. Estimativa do plastocrono em meloeiro (Cucumis melo L.) cultivado em estufa plástica em diferentes épocas do ano. Ciência Rural, v.35, p.1275-1280, 2005.

TAKEDA, F.; HOKANSON, S.C. Strawberry fruit and plug plant production in the greenhouse. Acta Horticulturae, n.626, p.283-285, 2003.

Received on April 7, 2010 and accepted on June 4, 2010 